\title{
Development of narrative macrostructure in monolingual preschoolers in Germany and impact of socio-economic status and home literacy environment
}

Entwicklung makrostruktureller Erzählfähigkeiten einsprachig deutscher Kindergartenkinder unter Berücksichtigung des Einflusses sozio-ökonomischer sowie Literacy-Variablen

\author{
Carina Marie Wehmeier \\ Leibniz Universität Hannover, Germany
}

The aim of this paper is to analyse the development of narrative macrostructure and the impact of socio-economic status (SES) and home literacy environment (HLE) on the narrative macrostructure of monolingual preschoolers in Germany when retelling and telling a story. The analysis of narrative macrostructure includes three components: story structure, story complexity, and story comprehension. Oral narratives were elicited via Multilingual Assessment Instrument for Narratives (LITMUS-MAIN). 198 monolingual children between age 4;6 and 5;11 participated ( $M=63$ months, $\mathrm{SD}=5$ months). The comparison of narrative macrostructure in three age groups $(4 ; 6$ to $4 ; 11$ years, $5 ; 0$ to $5 ; 5$ years, $5 ; 6$ to $5 ; 11$ years) illustrate significant age effects in story structure, story complexity and story comprehension skills. There were weak significant positive correlations of some of these skills with aspects of socio-economic status and home literacy environment, for example between story comprehension skills and the educational background, the frequency and duration of the child's exposure to books and the number of books in the household.

\section{Introduction}

Developmental growth in narrative comprehension and production has been shown within various studies (i.e. Berman 2009, Burris \& Brown 2014, Heilmann, Miller, Nockerts \& Dunaway 2010, Muñoz, Gillam, Peña, \& GulleyFaehnle 2003, Ukrainetz, Justice, Kaderavek, Eisenberg, Gillam \& Harm 2005). 
Narrative comprehension skills are developed by children between three and five years of age and improved until age nine when goal structures and inferences resemble adult comprehension skills (see the review in Burris \& Brown 2014). Skills in narrative production develop strongly between five and seven years of age (Berman 2009, Heilmann et al. 2010) but with further development up to age nine (Berman \& Slobin 1994, Kemper 1984, Trabasso \& Rodkin 1994). Narrative production and comprehension skills are acquired through interaction with peers and adults (Nelson 2010, Nicolopoulou, Brockmeyer, de Sá \& Ilgaz 2014), during which children are exposed to scaffolding behavior and obtain linguistic models (Vygotsky 1962).

The socio-economic status (SES) of a family is one of the most influential factors, which determines not only linguistic development, but also defines the future life path of a child (Noble, Engelhardt, Brito, Mack \& Nail 2015). Hart \& Risley (1995) found SES to dramatically affect children's lexicon: in their study, four-year-old children from prosperous family backgrounds had heard about thirty million words more than peers from disadvantaged family backgrounds. Additionally, children from lower SES families are provided with opportunities of language learning of lower quality (Cartmill, Armstrong, Gleitman, GoldinMeadow, Medina \& Trueswell 2013, Goldin-Meadow, Levine, Hedges, Huttenlocher, Raudenbush \& Small 2014, Rowe 2012); these children are worse off in both quantity and quality of their linguistic input (Pace, Luo, Hirsh-Pasek \& Michnick Golinkoff 2017). Much less is known about the relationship between narrative skills and SES (Pace et al. 2017).

The home literacy environment (HLE) also affects young children's language development (Rodriguez \& Tamis-LeMonda 2011). For example, the frequency of book exposure is significantly correlated with receptive vocabulary and oral expression (Carroll 2013, Crain-Thoreson \& Dale 1992, Fletcher, Cross, Tanney, Schneider \& Finch 2008, Whitehurst, Arnold, Epstein, Angell, Smith \& Fischel 1994). Measures of the home literacy environment like the frequency of shared reading and literacy activities are related to socioeconomic status and to family living circumstances (Phillips \& Lonigan 2009). There are few investigations of how aspects of the home literacy environments are linked to narrative skills (Bitetti \& Scheffner-Hammer 2016).

This paper analyses the development of narrative macrostructure of monolingual German preschoolers aged 4;6 to 5;11 and the impact of socioeconomic variables (SES) and home literacy environment (HLE) on the narrative macrostructure when retelling and telling a story. For this purpose, the Multilingual Assessment Instrument for Narratives (LITMUS-MAIN) (Gagarina et al. 2012, 2015) of the Language Impairment Testing in Multilingual Settings (LITMUS) test battery (Armon-Lotem, Meir, \& de Jong, 2015) was used to examine children's narrative macrostructure when retelling and telling a story in German, while SES and HLE were assessed using a parent questionnaire. 


\section{Narrative macrostructure}

\subsection{Narrative assessment}

Narrative macrostructure can be assessed using production and comprehension tasks. Usually the telling mode and the retelling mode are differentiated. Retold narratives of a story told to children before, strongly rely on short-term memory skills. Children essentially retell what they remember often using similar expressions and formulations. In contrast to that told narratives allow the child to choose vocabulary and syntactic structures to tell the events of the story (Otwinowska, Mieszkowska, Białecka-Pikul, Opacki \& Haman 2018). There are several studies comparing the effects of different narratives methods (retelling vs. telling) in relation to the narrative structure (e.g. Isbell, Sobol, Lindauer \& Lowrance 2004, Kaikhosroshvili 2016, Kunnari, Välimaa \& Laukkanen-Nevala 2016, Maviş, Tunçer \& Gagarina 2016, Roch, Florit \& Levorato 2016). Either retelling a story could improve the child's narrative performance (Isbell, Sobol, Lindauer \& Lowrance 2004, Maviş et al. 2016, Kunnari et al. 2016, Otwinowska et al. 2018, Peterson \& McCabe 1991) or there could be adverse effects, if vocabulary and syntactic constructions do not match the child's proficiency level (Gutiérrez-Clellen 2002, Sénéchal, Pagan, Lever \& Ouellette 2008, Vygotsky 1962). Children retelling a story looking at a picture-sequence produced more complex narratives than telling a story (Kunnari et al. 2016, Maviş et al. 2016, Roch et al. 2016). Without a picture-sequence, findings indicate that in retold narratives, language is less complex compared to stories made up by the child without a picture-sequence (Gutiérrez-Clellen 2002).

Picture-sequences complemented by standardized instructions are usually selected to assess narrative abilities in children, because of the benefit of comparable results of the children (Bartl, Vollmann, Strutzmann \& Marschik 2011, Norbury \& Bishop 2003, O’Neill, Pearce \& Pick 2004, Oktay 2010, Ringmann 2014, Shiro 2003, Spencer, Kaijan, Petersen \& Bilyk 2013). Pictureprompted narrative tasks elicit the shortest and most cognitively demanding narratives compared to for example stories about experiences of the child (Becker 2011). Children telling a story according to a picture book often cannot utilize the narrative skills in that task, which they use during conversational situations with parents and peers (Becker \& Licandro 2014). Nevertheless, picture-sequences are used in quantitative studies due to the methodological advantage to standardize the assessment and evaluation of narrative skills in children along with the possibility to compare the results of the children to each other (Bartl et al. 2011, Norbury \& Bishop 2003, O’Neill et al. 2004, Oktay 2010, Ringmann 2014, Shiro 2003, Spencer et al. 2013).

Macrostructure, together with microstructure, creates the base of a coherent and cohesive narrative, which is comprehensive to the listener (Liles, Duffy, Merritt \& Purcell 1995, Ringmann 2013). Macrostructure is the structural organization of the narrative content and less language dependent than 
microstructure, which includes linguistic structures like a uniform tense as well as language specific referring expressions, sentence-linking and ritualized phrases (Gagarina et al. 2012, 2015, Justice, Bowles, Kaderavek, Ukrainetz, Eisenberg \& Gillam 2006, Pavlenko 2008, Ringmann 2014).

The present paper concentrates on macrostructure only, which creates the coherence of a story focusing on the sequence of events. This global organization of a narrative is described for example within story grammar models (Mandler 1979, Stein \& Glenn 1979). The story grammar consists of several story elements. The setting is necessary to describe time and place of the action and introduce the characters. Afterwards an internal response of the main character leads to an internal plan or goal and an attempt to reach these. An outcome or consequence follows the action of the character as well as an internal reaction to this outcome (Peterson \& McCabe 1991, Stein \& Glenn 1979). The analysis of the presence of these components in a narrative is referred to as a story structure (Gagarina et al. 2012, Trabasso \& Nickels 1992).

The story structure builds the base to analyse the macrostructure more deeply. The so-called structural complexity of a story can be measured focusing on the story structure elements goal, attempt and outcome. Especially younger children's narratives often lack one or more of these elements. Westby (2012, 2005) classified several complexity levels of narratives using a binary decision tree, which differentiates between: descriptive sequences, that include either an attempt or an outcome (A or $\mathrm{O}$ ) without temporal relation, action sequences, that comprise temporal but not causally related attempt and outcome, but no goal statement $(\mathrm{AO})$, reactive sequences, that contain causally related attempt and outcome, but no implicit goal-directed behaviour (AO), abbreviated episodes that include an attempt, or an outcome in addition to a goal (GA or GO), and complete episodes, that contain a goal, an attempt and an outcome (GAO). While a descriptive or action sequence displays a low structural complexity, the complete episode represents the highest level of story complexity. The production of GAOs indicates the ability to produce a coherent story (McCabe \& Peterson 1984, Trabasso \& Nickels 1992, Westby 2005).

Besides the analysis of macrostructure measures in narrative production, narrative comprehension can also be assessed. Comprehension questions that focus on story structure elements, which are interpreted as a marker for children's understanding and awareness of intentionality and goal-directed behavior of protagonists, can be used to assess macrostructure comprehension (Gagarina et al. 2012).

The present paper investigates the three macrostructure measures story structure, story complexity and story comprehension assessed in both elicitation methods - telling and retelling - using two picture-sequences of the LITMUSMAIN (Gagarina et al. 2012). 


\subsection{Development of narrative macrostructure}

Interaction with peers and adults creates possibilities for the child to acquire narrative production and comprehension skills (Nelson 2010, Nicolopoulou et al. 2014). Occasions like spontaneous storytelling as well as sharing knowledge and experiences afford opportunities for the child to obtain linguistic models and be exposed to scaffolding behavior (Nelson 2010, Vygotsky 1962). Narrative macrostructure production develops towards creating a coherent story with adequate evaluative content, background information, mental states, integration of individual events and top-down narrative structures (Berman 2009). Various studies describe developmental growth in narrative macrostructure production and comprehension in monolingual and bilingual children (Bohnacker 2016, Gagarina 2016, Heilmann et al. 2010, Kunnari et al. 2016, Lindgren 2018, Maviş et al. 2016, Muñoz et al. 2003, Roch et al. 2016, Ukrainetz et al. 2005).

The development of narrative comprehension reaches a critical period between three and five years of age. From age six, these processes continue to be refined until age nine, when sensitivity to goal structures and inferences resemble adult comprehension (see the review in Burris \& Brown 2014).

Kemper (1984), Muñoz et al. (2003) and Trabasso \& Rodkin (1994) described a development from producing unrelated elements of the story structure to the understanding and producing of GAO-structures of children aged three to five. Four-year-olds are able to express temporal relations of events (Stein 1988), whereas at age five the highest level of macrostructure complexity including causal relations can be reached (Trabasso \& Rodkin 1994). Berman and Slobin (1994) described the production of narratives with a hierarchical organisation around the goal of the protagonist at the ages between six and ten, whereas Heilmann, Miller and Nockerts (2010) found the age of five to seven years to be of high importance. Moreover, Trabasso and Rodkin (1994) and Kemper (1984) mentioned a further development of story complexity up to age nine.

A number of studies focusing on narrative production and comprehension skills have been carried out using LITMUS-MAIN, the material used in the present study. However, most of these studies are on bilinguals (Altman, Armon-Lotem, Fichman \& Walters 2016, Bohnacker 2016, Gagarina 2016, Kapalková, Polisenská, Marková \& Fenton 2016, Maviş et al. 2016, Otwinowska et al. 2018, Roch et al. 2016, Tsimpli, Peristeri \& Andreou 2016); only a few include data from monolinguals as well (Kunnari et al. 2016, Lindgren 2018).

For example, Lindgren (2018) analysed narrative macrostructure in 166 monolingual and bilingual Swedish preschoolers aged 4;0 to 6;11 using LITMUS-MAIN. Regarding the monolingual Swedish children, Lindgren (2018) found significant effects of age on both story comprehension and story production (story structure; story complexity: four levels) with older children performing better. In addition to a general increase with age in story structure scores, Lindgren (2018) found most age development on attempts and outcomes, 
while she found no age development in the production of goals within her study. However, there was a significant increase in the use of GAOs, i.e. complete episodes with age.

Roch et al. (2016) assessed narrative macrostructure in 62 Italian-English sequential bilingual children: 30 preschoolers $(\mathrm{M}=5 ; 5$ years) and 32 first graders $(\mathrm{M}=6 ; 6$ years) using LITMUS-MAIN. They found significant effects on story structure, story complexity and story comprehension regarding age, with preschoolers scoring lower than first graders, as well as narrative method, with children scoring higher retelling than telling a story.

\subsection{Environmental influences on narrative macrostructure}

Because narrative skills are acquired through interaction (Nelson 2010, Nicolopoulou et al. 2014) and therefore are influenced by the environment of the child, there might be an impact of family's SES and HLE measures on children's narrative macrostructure (Roch et al. 2016).

\subsubsection{Socio-economic status}

The multidimensional SES is composed of the access to financial, educational and social resources and the social positioning and prestige (Duncan, Magnuson \& Votruba-Drzal 2015, Pace et al. 2017). To measure SES, mostly parental education, family income and parental occupation variables are assessed (Bradley \& Corwyn 2002, Ensminger \& Fothergill 2003).

The educational level of the mother is the SES variable that seems to associate to child language development outcomes the best and is most frequently assessed in several studies (Alt, Arizmendi \& DiLallo 2016, Arriaga, Fenson, Cronan \& Pethick 1998, Burchinal, Peisner-Feinberg, Pianta \& Howes 2002, Corsaro, Molinari \& Rosier 2002, Fernald, Marchman \& Weisleder 2013, Hart \& Risley 1995, 1999, Pace et al. 2017, Rodriguez \& Tamis-LeMonda 2011, Van Kleeck, Lange \& Schwarz 2011).

The educational background is usually measured as a categorical variable representing groups with various levels of formal schooling ranging for example from no high school education to a college degree (Hoff, Laursen \& Bridges 2002, Magnuson, Sexton, Davis-Kean \& Huston 2009).

To investigate family income, frequently used options are to assess the annual salary to classify families as above or below the federal poverty threshold (Taylor, Dearing \& McCartney 2004) or to create an income-to-need ratio to reflect the amount of poverty or affluence experienced (Duncan, Brooks-Gunn \& Klebanov 1994, McLoyd 1998).

To assess the parental occupation, investigations use for example the International Standard Classification of Occupations (ISCO 08, International Labour Organization 2008) to compare occupations across different countries. The parental occupation is measured as a categorical variable representing 
groups with various levels ranging from managers to workers in elementary occupations (OECD 2014).

Language skills of monolingual children associate positively with the different measures of SES (Arriaga et al. 1998, Bowey 1995, Fernald et al. 2013, Ginsborg 2006, Hart \& Risley 1995, 1999, Hoff 2006, Pungello, Iruka, Dotterer, Mills-Koonce \& Reznick 2009, Rodriguez \& Tamis-LeMonda 2011, Walker, Greenwood, Hart \& Carta 1994). Gaps in language comprehension and production between children from high and low SES-backgrounds occur and remain stable or even widen over time (Fernald et al. 2013, Walker et al. 1994) and they are predictive of later academic success and school problems (Burchinal, Pace, Alper, Hirsh-Pasek \& Golinkoff 2016, Burchinal et al. 2002, Entwisle \& Alexander 1999, Hoff 2013). Only limited and contradicting results are available regarding the relationship between socioeconomic status and narrative abilities (Alt et al. 2016, Corsaro et al. 2002, Korat 2009, Mozzanica, Ambrogi, Salvadorini, Sai, Pozzoli, Barillari, Scarponi \& Schindler 2016, Peterson 1994, Reese, Suggate, Long \& Schaughency 2009, Van Kleeck et al. 2011).

For example, Reese et al. (2009) investigated the link between mothers' educational background and oral narrative retelling skills of monolingual English-speaking children the age of six $(\mathrm{N}=61)$ and seven $(\mathrm{N}=39)$. Maternal education did not significantly correlate with any of the oral narrative measures, but the small range of maternal education level (no university background included) may have blurred the impact on the children's retells.

Van Kleeck et al. (2011) included 172 children in their study (86 African American, 86 European American). The authors compared preschoolers retelling the Renfrew Bus Story measuring the amount of information included, sentence length and story complexity. The preschoolers' mothers had an education level of high school or less $(<\mathrm{HS})$ or higher than high school $(>\mathrm{HS})$. The analysis showed significant differences between groups on information score, sentence length and story complexity with $<$ HS scoring lower.

Mozzanica et al. (2016) studied 505 typically developing Italian children using the Renfrew Bus Story. The authors identified significant positive correlations for mother's and father's educational background and the child's narrative abilities as measured by information score, sentence length and story complexity. However, when considered together, only the father's educational level impacts the child's story complexity and information score.

Alt et al. (2016) examined the link between maternal education level and narrative structure in Spanish and English story retells using language samples from 907 bilingual children (398 preschoolers, $M=5 ; 7$ years; 509 second graders, $\mathrm{M}=7 ; 7$ years). There were no differences between children with different maternal educational level regarding narrative structure for the Spanish language samples, but there were differences with the English language samples with children of higher educated mothers scoring better (with a small percentage of the variance explained). 
There is evidence that children from low-SES homes who engage in more co-storytelling in daily life produce narratives of higher quality and have better narrative comprehension than their middle-class counterparts (Burger \& Miller 1999, Gardner-Neblett, Pungello \& Iruka 2012).

For the purposes of this study, the educational background of the mother and father as well as the monthly household income were assessed.

\subsubsection{Home literacy environment}

Research into the home literacy environment (HLE) reveals its importance for children's development of emergent literacy skills and oral language (Hamilton, Hayiou-Thomasb, Hulmec \& Snowling 2016, Justice \& Pullen 2003, Puglisi, Hulme, Hamilton \& Snowling 2017, Rodriguez \& Tamis-LeMonda 2011). Aspects of HLE are related to socioeconomic status, to family living circumstances, caregiver stress, and caregiver reading ability (Dickinson \& Tabors 2001, Phillips \& Lonigan 2009, Scarborough \& Dobrich 1994).

There are different ways to evaluate HLE. Most studies assess the frequency of literacy activities and the amount of literacy materials (Bitetti \& Scheffner-Hammer 2016, Bus, van Ijzendoorn \& Pellegrini 1995, Carroll 2013, Hamilton et al. 2016, Puglisi et al. 2017). Items regarding the frequency of shared reading and storytelling as well as the number of children's books at home are regularly used (Bitetti \& Scheffner-Hammer 2016, Carroll 2013, Leseman, Scheele, Mayo \& Messer 2007, Puglisi et al. 2017).

Carroll (2013) additionally includes the quality of parents dialogic reading techniques, the child's interest in reading books by him-/herself and with a parent, the child's engagement during book reading, the frequency the child pretends to write in her study.

Puglisi et al. (2017) additionally assess the frequency of the parents' direct literacy instructions like teaching the child to recognise letters and to read or write words, the maternal familiarity with the child's books and adult fiction. The authors state that parents engaging frequently in shared reading activities recognise more books and parents reading a lot read more books with their children.

A detailed analysis of HLE may additionally include variables like the duration of daily exposure to books of the child and the total number of books at home (Bitetti \& Scheffner-Hammer 2016, Bus et al. 1995, Hamilton et al. 2016). The total number of books in the household is not only a measure of HLE, but also a rarely used but valid measure of the family's socio-economic background (De Graaf 1988, Esping-Andersen 2004), because this variable correlates strongly with the household income. It accounted for the highest percentage of variance of all socio-economic measures in schoolchildren's differences in reading, writing and mathematics skills in German children within PISA and TIMMS (Schütz, Ursprung \& Wößmann 2008). Additionally, this variable does 
not evoke that many missing answers within a questionnaire like for example the household income (Schütz \& Wößmann 2005).

It is well known that HLE has a considerable impact not only on early language acquisition (Bus et al. 1995, Justice \& Pullen 2003, Rodriguez \& Tamis-LeMonda 2011, Van Kleeck, Gillam, Hamilton, \& McGrath 1997, Whitehurst \& Lonigan 1998), but also on the emergence of literacy in children (Bus et al. 1995, Carroll 2013, Mol, Bus, De Jong \& Smeets 2008, Scarborough $\&$ Dobrich 1994). HLE and SES measures are positively correlated, i.e. the frequency of parents reading to their preschooler is related to SES (Dickinson \& Tabors 2001, Phillips \& Lonigan 2009, Scarborough \& Dobrich 1994). The role of HLE for the development of narrative skills has been investigated in a number of studies (Bitetti \& Scheffner-Hammer 2016, Hindman, Connor, Jewkes \& Morrison 2008, Korat 2009, Leseman et al. 2007).

Leseman et al. (2007) analysed the link between HLE and academic language (assessed with narrative comprehension and production tasks) in 68 four-year-old Dutch children. There were moderate to strong correlations for children's academic language and HLE. HLE and working memory predicted children's vocabulary and narrative comprehension and production skills telling and retelling a story.

Bitetti \& Scheffner-Hammer (2016) gathered longitudinal data between preschool-age and first grade from 81 Spanish-English bilingual children from low-income backgrounds to examine the impact of HLE on narrative macrostructure development. The frequency with which mothers read to their children had a positive impact on the growth of the children's total narrative scoring scheme scores (comparable with story structure). Other aspects of the home literacy environment, such as the frequency of the mother telling stories or the total number of picture books of the family, did not affect macrostructure development.

In the present study, only particular measures of HLE were included, which are the frequency of book exposure and shared reading experiences, the duration of daily exposure to books and the total number of books at home.

\section{The present study}

The present study is part of an ongoing dissertation project investigating narrative abilities, nonverbal cognitive skills, auditory processing, language abilities and the family background of 436 monolingual and bilingual Germanspeaking children aged 4;0 to 6;11. Children with delays in one or more areas of child development and, concerning the bilingual children, less than twelve months of regular German language acquisition, were excluded from the project. Children were recruited from various kindergartens in the German federal states Lower Saxony, Hesse and Schleswig-Holstein.

The children were assessed using tests and standardized tools: narrative abilities via Multilingual Assessment Instrument for Narratives (LITMUS- 
MAIN, Gagarina et al. 2012), wordless picture book „Frog, where are you?” (Mayer 2003), subscale five and six of the Test of narrative language (TNL, Gillam \& Pearson 2004), language production and comprehension skills via Linguistische Sprachstandserhebung - Deutsch als Zweitsprache (Lise DaZ, Schulz \& Tracy 2011), auditory perception and processing via Heidelberger auditive Screening (HASE, Schöler \& Brunner 2008) as well as nonverbal cognitive skills via Coloured Progressive Matrices (CPM, Raven, Bulheller \& Häcker 2006). A parental questionnaire was included to gain information on the child's overall development as well as family measures like socio-economic status and home literacy environment.

This paper aims to describe the development of narrative macrostructure in monolingual children aged 4;6 to 5;11 and examine the links between these narrative skills and aspects of SES and HLE. The following research questions were asked:

1. Do story structure, story complexity and story comprehension differ between children aged $4 ; 6$ to $4 ; 11,5 ; 0$ to $5 ; 5$ and $5 ; 6$ to $5 ; 11$ years?

2 . Do story structure, story complexity and story comprehension differ between the children telling and retelling a story?

3. Do SES and HLE correlate significantly with the children's narrative macrostructure production and comprehension when telling and retelling a story?

A number of studies has described improvement in narrative macrostructure in four- to six-year-old children (e.g. Bohnacker 2016, Heilmann et al. 2010, Kunnari et al. 2016, Lindgren 2018, Maviș et al. 2016, Muñoz et al. 2003, Roch et al. 2016, Ukrainetz et al. 2005). Thus, significant differences between the age groups are expected.

Differences between telling and retelling are difficult to predict, because some studies show that retelling a story improved the child's narrative performance (Maviş et al. 2016, Kunnari et al. 2016) whereas others showed the opposite (Gutiérrez-Clellen 2002, Sénéchal et al. 2008, Vygotsky 1962).

Overall, significant positive correlations between narrative macrostructure and SES as well as HLE are expected, as evidenced by previous studies (i.e. Bitetti \& Scheffner-Hammer 2016, Korat 2009, Mozzanica et al. 2016, Reese et al. 2009, Van Kleeck et al. 2011).

\section{$4 \quad$ Method}

A total of 198 monolingual German-speaking boys and girls aged $4 ; 6$ to $5 ; 11$ years $(\mathrm{M}=63$ months, $\mathrm{SD}=5$ months) participated in this study (see Table 1 ). The preschoolers were divided into three age groups $(4 ; 6$ to $4 ; 11,5 ; 0$ to $5 ; 5$ and $5 ; 6$ to $5 ; 11$ years) to create a broader picture of the development of narrative 
macrostructure. Written informed consent of the parents were given for each child to participate in this study.

Table 1: Mean age (SD) and gender of the three age groups

\begin{tabular}{lllll}
\hline Age group & Male & Female & All & $\begin{array}{l}\text { Mean age in } \\
\text { months (SD) }\end{array}$ \\
\hline $4 ; 6-4 ; 11$ & 25 & 31 & 56 & $56.5(1.6)$ \\
\hline $5 ; 0-5 ; 5$ & 29 & 34 & 63 & $62.8(1.9)$ \\
\hline $5 ; 6-5 ; 11$ & 38 & 41 & 79 & $68.7(1.4)$ \\
\hline All & 92 & 106 & 198 & $63.4(5.3)$ \\
\hline
\end{tabular}

\subsection{Instruments}

Two picture-sequences from the Multilingual Assessment Instrument for Narratives (LITMUS-MAIN) (Gagarina et al. 2012, 2015) of the Language Impairment Testing in Multilingual Settings (LITMUS) test battery (ArmonLotem et al. 2015) were used to assess the children's narrative skills. The Cat story was used to examine the children's narrative macrostructure when retelling a story, while the Baby Birds story was used to assess the children's narrative macrostructure when telling a story without the child having previously heard it. Each child spontaneously with the aid of a picture-sequence told the Baby Birds story. The Cat story was retold with the aid of a picture-sequence, after an adult had provided each child with a model story. After each story was (re)told, ten standardised comprehension questions focusing on goals, internal states and explanations of internal states as well as the general plotline were asked.

Aspects of SES and HLE were assessed using a parental questionnaire. The single choice categorical variables measured the mean monthly family income, the educational background of both parents, the number of books in the household, the mean duration of book exposure of the child a day, the mean frequency of book exposure in dyads and alone a week.

\subsection{Procedure}

The first acquaintance of each child and the respective experimenter took place within the child's kindergarten group, where the experimenters spent time to form a trust-based relationship with each child. If the child expressed verbal consent to participate in the study, the session took place individually in a separate room in the child's kindergarten. Trained masters of rehabilitation pedagogy students administered the German version of the LITMUS-MAIN to all children. Narrative skills were assessed in the retelling mode first, before a story was elicited in the telling mode, i.e. Cat story was always retold before Baby Birds story was told. 
For the first part of the assessment, the retelling of the Cat story, the experimenter placed three closed envelopes (each one containing the Cat picture-sequence) on the table and asked the child to choose one. After the child took the set of six pictures out of the chosen envelope and gave it to the experimenter, the experimenter unfolded the pictures in the non-shared attention modus (i.e. the picture-sequence is visible only to the child). After the child had looked through the picture-story, the experimenter told the story to the child while both were looking at the pictures. Hereafter, the child was asked to retell the story before the experimenter asked the ten standardized comprehension questions regarding goals, actions, internal states and explanations of the internal states of of the characters.

Next, the experimenter moved to the second part of the assessment, the telling of Baby Birds. The experimenter placed another three closed envelopes (each one contained the Baby Birds picture-sequence) on the table and asked the child to choose one and to tell the story after looking at the pictures in the nonshared attention modus. Finally, the experimenter asked the child the ten standardized comprehension questions regarding goals, actions and internal states of the characters.

The whole assessment was audio recorded and each narrative was transcribed in the CHAT format (MacWhinney 2000) by trained transcribers. Ten percent of the audio files $(\mathrm{N}=38)$ was transcribed by two trained transcribers and interrater reliability was checked calculating Cohen's Kappa (the reliability score was $90.1 \%$ ).

\subsection{Scoring}

Both Cat story and Baby Birds story visualise three different episodes in one setting. Each story structure element of each episode is scored. The setting of the story is scored with a maximal score of two points, one point for the time and one point for the place of the story. Each episode included an internal state of the main character as initiating event, which leads to an internal goal and an attempt to reach it. The outcome follows the action of the character as well as an internal state as reaction to this outcome. Each story structure element in each episode is scored with a maximum of one point. The story structure has a maximal score of seventeen points (Gagarina et al. 2012).

Story complexity is scored for each episode as well. Based on Westby's (2005) binary decision tree six different complexity levels are differentiated. The analysis of the story complexity focuses on the combination of goals, attempts and outcomes of each episode. An episode without any of these three elements (neither attempt, A; outcome, O; nor goal, G) is scored with zero points, while a single $\mathrm{A}$ or $\mathrm{O}$ is scored with one point. If $\mathrm{A}$ and $\mathrm{O}$ are both part of the episode, two points are awarded. A single goal statement gives three points, while GA or GO are scored with four points. If the child is able to 
include a goal, an attempt and an outcome (GAO) in the episode, the maximal score of five points is awarded. The sum of the scores of the three episodes results in a maximal story complexity score of fifteen points.

Story comprehension was assessed with ten standardized comprehension questions for each MAIN story. The questiones focused on story structure elements, which are interpreted as markers for children's understanding and awareness of intentionality and goal-directed behavior of protagonists. Three comprehension question targeted the three goals of the main characters (one in each of the three episodes). Six questions elicit internal state terms connected to either the initiating event or reaction element and the child's explanations for these terms. The last question probes theory of mind to see if the child can infer meaning about the story as a whole (Gagarina et al. 2012). Each comprehension question answered correctly was scored with one point, giving a maximal score of ten points.

Aspects of SES and HLE were assessed using a parent questionnaire. Single choice categorical variables measured the mean monthly family income (5-point scale; 1. 1,000€ or less, 2. about 2,000€, 3. about 3,000€, 4. about $4,000 € 5$. 5,000€ or more) the educational background of both parents (5-point scale: 1. no school-leaving qualification, 2. secondary school (Hauptschulabschluss), 3. secondary school (Realschulabschluss), 4. grammar school (Fachhochschulreife/Abitur), 5. bachelor/master degree (universitärer Abschluss)), the number of books in the household (5-point scale: 1. 0-10 books, 2. 11-25 books, 3. 26-100 books, 4. 101-200 books, 5. more than 200 books), the mean duration of book exposure of the child per day (3-point scale: 1. less than 15 minutes, 2. 15-45 minutes, 3 . more than 45 minutes), the mean frequency of book exposure with parents and alone per week (both 9-point scales: 1. never, 2. less than once, 3. once, 4. twice, 5. 3 times, 6. 4 times, 7. 5 times, 8.6 times, 9. daily).

\section{$5 \quad$ Results}

First, the mean values (Figure 1) and the results of the ANOVAs of the comparison of the macrostructure skills of the three age groups are reported. Due to missing data, the results are based on calculations including 173 (for comprehension questions of both stories) to 198 children (for both story structure and story complexity of both stories).

Starting with story structure, the main effect of age group for the retelling task (Cat story) was statistically significant $\left(\mathrm{F}(2,185)=5.363, \mathrm{p}=.005, \eta^{2}=0.055\right)$. Post-hoc analyses showed that the youngest children's $(4 ; 6-4 ; 11$ years) mean result of 6.3 points $(\mathrm{SD}=2.1)$ differed significantly from the outcome of the eldest group (5;6-5;11 years, $\mathrm{M}=7.7, \mathrm{SD}=2.4)$. The main effect of age group for the telling task (Baby Birds story) was also statistically significant $\left(F(2,198)=12.334, p<.001, \eta^{2}=0.105\right)$ as well. Post-hoc analyses showed that the eldest children's $(5 ; 6-5 ; 11$ years) mean result of 6.9 points $(\mathrm{SD}=1.9)$ was 
significantly higher than the outcomes of both younger groups. Keeping in mind that the maximal score for story structure was seventeen points, there is obviously growth potential in narrative story structure telling and retelling a story for school aged children.

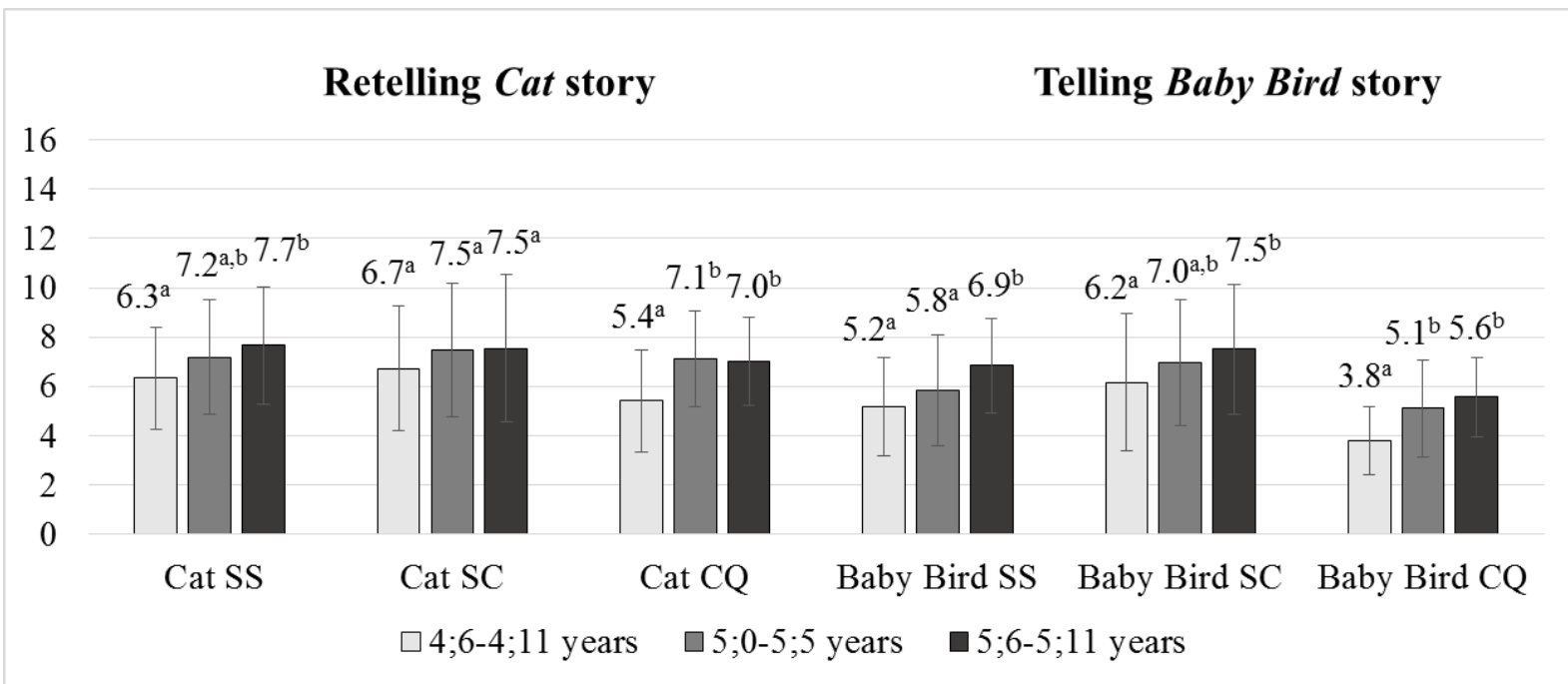

Figure 1: Mean values and standard deviations of the three age groups $(4 ; 6-4 ; 11,5 ; 05 ; 5,5 ; 6-$ $5 ; 11$ years) in story structure ( $\mathrm{SS}$, maximum of 17 points), story complexity (SC, maximum of 15 points) and story comprehension (CQ, maximum of 10 points) retelling Cat and telling Baby Birds story of LITMUS-MAIN (Gagarina et al. 2012).

Note. Different indices (letters a, b, c) show statistically significant differing results of the age groups. The same indices indicate no statistically significant differences.

Regarding story complexity, there were no statistically significant differences between the three age groups retelling the Cat story $(\mathrm{F}(2,184)=1.482, \mathrm{p}=.230)$. Concerning the telling task (Baby Birds story), the main effect of age group was statistically significant, but the effect size (partial eta ${ }^{2}$ ) is quite small $\left(\mathrm{F}(2,198)=4.339, \mathrm{p}=.014, \eta^{2}=0.014\right)$. Post-hoc analyses showed that the eldest children's $(5 ; 6-5 ; 11$ years $)$ mean result of 7.5 points $(\mathrm{SD}=2.6)$ was significantly higher than the outcome of the youngest children (4;6-4;11 years, $M=6.2$, $\mathrm{SD}=2.8)$. There were no statistically significant differences for the middle age group $(5 ; 0-5 ; 5$ years) from the other groups.

The analysis concerning story comprehension showed statistically significant main effects of age group for both the retelling task (Cat: $\mathrm{F}(2,179)=14.133, \mathrm{p}<.001, \eta^{2}=0.138$ ) and the telling task (Baby Birds: $\left.\mathrm{F}(2,198)=18.199, \mathrm{p}<.001, \eta^{2}=0.159\right)$. For both tasks, post-hoc analyses showed that the youngest children's results $(4 ; 6-4 ; 11$ years, Cat: $\mathrm{M}=5.4, \mathrm{SD}=2.1$, Baby Birds: $\mathrm{M}=3.8, \mathrm{SD}=1.6)$ were significantly lower than those of the two other groups.

The repeated-measures ANOVAs showed overall statistically significant main effects for the mode of narration (retelling vs. telling). The effect regarding story structure $\left(\mathrm{F}(1,181)=36.345, \mathrm{p}<.001, \eta^{2}=0.167\right)$ and story comprehension 
$\left(\mathrm{F}(1,173)=14.133, \mathrm{p}<.001, \eta^{2}=0.420\right)$ were strong, in contrast to the quite small effect relating to story complexity $\left(\mathrm{F}(1,180)=5.724, \mathrm{p}=.018, \eta^{2}=0.031\right)$. There was no main effect of age within these calculations and there were no significant interactions between age group and mode of narration. The children in all age groups achieved higher scores in story structure, story complexity and story comprehension retelling the Cat story than telling the Baby Birds story.

Now, the links between family background measures (SES and HLE) and the macrostructure variables story structure, story complexity and story comprehension are illustrated (Table 2). Because there are no statistically significant differences between the three age groups in relation to the SES and HLE measures, all children of the sample were considered together within the calculations of correlations. Due to missing data, calculations are based on data of 127 (household income) to 198 (other SES and HLE variables) families. The different aspects of HLE and SES showed only weak significant positive correlations to each other, which is why no overall dimension was created and each aspect of SES and HLE was considered individually.

Table 2: Correlation coefficients ( $r$ ) between the SES and HLE measures and the macrostructure measures story structure (SS), story complexity (SC) and comprehension questions (CQ) of the preschoolers retelling Cat story and telling Baby Bird story. Only statistically significant correlations are listed.

\begin{tabular}{|c|c|c|c|c|c|c|}
\hline Environmental influences & $\begin{array}{l}\text { Cat } \\
\text { SS }\end{array}$ & $\begin{array}{l}\text { Cat } \\
\text { SC }\end{array}$ & $\begin{array}{l}\text { Cat } \\
\text { CQ }\end{array}$ & $\begin{array}{l}\text { Bird } \\
\text { SS }\end{array}$ & $\begin{array}{l}\text { Bird } \\
\text { SC }\end{array}$ & $\begin{array}{l}\text { Bird } \\
\text { CQ }\end{array}$ \\
\hline Books/household & $.190^{*}$ & & $.170^{*}$ & & & $.246^{* *}$ \\
\hline Book exposure/alone & & & $.184^{*}$ & & & $.186^{*}$ \\
\hline Book exposure/with parent & & & & & $-.156^{*}$ & \\
\hline Book exposure/duration & & & & & & $.158 *$ \\
\hline Education/mother & & & & & & $.223 * *$ \\
\hline Education/father & & $-.204^{*}$ & $.185^{*}$ & & & $.262 * * \mathrm{a}$ \\
\hline Household income/month & & & & & & \\
\hline
\end{tabular}

Notes. ${ }^{*}=\mathrm{p}<.05,{ }^{* *}=\mathrm{p}<.01 . ;^{\mathrm{a}}=$ This result remained statistically significant after Bonferroni corrections.

The total number of books in the household correlated weakly positive with the story structure retelling $\left(\mathrm{r}=.19^{*}\right)$ and story comprehension for retelling $\left(\mathrm{r}=.17^{*}\right)$ and telling $\left(\mathrm{r}=0.25^{* *}\right)$. The exposure of the child to books alone correlated weakly positive with story comprehension for retelling $\left(\mathrm{r}=0.18^{*}\right)$ and telling $\left(\mathrm{r}=0.19^{*}\right)$. The mean duration of book exposure of the child correlated with story comprehension for telling $\left(\mathrm{r}=0.16^{*}\right)$.

The educational background of the mother was linked to story comprehension in telling $(\mathrm{r}=0.22 * *)$, while the educational background of the father correlated with the child's story comprehension for retelling $\left(\mathrm{r}=0.19^{*}\right)$ and telling $\left(\mathrm{r}=0.26^{* *}\right)$. Two weak but significant negative correlations attracted 
attention: first, educational background of the father and story complexity for retelling $\left(\mathrm{r}=-0.20^{*}\right)$, second, the exposure of the child to books in dyad with a parent and story complexity for telling $\left(\mathrm{r}=-0.16^{*}\right)$. When Bonferroni corrections were used, only the correlation between the educational background of the father and the child's comprehension for telling remained statistically significant $\left(\mathrm{r}=0.26^{* *}\right)$.

\section{Discussion and conclusion}

This paper described the development of narrative macrostructure in monolingual German children $(\mathrm{N}=198)$ aged $4 ; 6$ to $5 ; 11(\mathrm{M}=63$ months, $\mathrm{SD}=5$ months) and examined the links between these narrative skills and aspects of socio-economic status and home literacy environment.

With regard to the development of macrostructure, statistically significant differences between the three age groups $(4 ; 6$ to $4 ; 11 ; 5 ; 0$ to $5 ; 5 ; 5 ; 6$ to $5 ; 11)$ were found. There were strong effects of age group for story comprehension both in telling and in retelling. A medium effect size was found for story structure in telling and small effects on story complexity in telling and story structure in retelling. No statistically significant difference was found for story complexity in retelling. There were age-independent statistically significant differences between the elicitation modes (retelling>telling) for all macrostructure measures. The results are in line with earlier studies that described a development in narrative macrostructure in four- to six-year-old children (Heilmann et al. 2010, Kunnari et al. 2016, Lindgren 2018, Maviş et al. 2016, Muñoz et al. 2003, Roch et al. 2016, Ukrainetz et al. 2005). For example, Lindgren (2018) found similar results for Swedish, regarding story structure and story comprehension (higher scores in older children) as well as in story complexity (complete episodes were relatively rare in all age groups, but there was a development with age). Different studies mentioned a further development of narrative macrostructure up to age ten (Berman \& Slobin 1994, Heilmann et al. 2010, Kemper 1984, Trabasso \& Rodkin 1994), which seems likely given the low mean values for even the eldest children $(5 ; 6-5 ; 11$ years) in the present study.

Because the children in the present study performed better on the retelling than on the telling task, the model story seemed to have improved the child's narrative performance like described in some studies (i.e. Isbell et al. 2004, Kunnari et al. 2016, Maviş et al. 2016, Otwinowska et al. 2018, Peterson \& McCabe 1991). This effect was seen in the current study despite the fact that retelling was carried out before telling (i.e. when the children told Baby Birds story, they had already heard and retold the Cat story). However, Lindgren (2018) found that children scored higher on MAIN Cat than on Baby Birds in comprehension, despite the fact that both tasks were used in the telling mode. 
The impact of SES and HLE measures on narrative macrostructure turned out to be small or nonexistent. Family income did not correlate significantly with any narrative skill. When Bonferroni corrections were used, only the educational background of the father correlated significantly with the story comprehension of the children telling a story; children whose father had higher education performed higher than children who had fathers with lower education. Mozzanica et al. (2016) found similar results: considered together, only the father's educational background had an impact on child's narrative abilities. That the impact of the education background of the mother on the narrative productions is small, is similar to the results of Alt et al. (2016), who assessed story structure in school-aged Spanish-English bilinguals. In contrast to the results of Bitetti \& Scheffner-Hammer (2016), the frequency of shared bookreading activities did not have a positive impact on the children's story structure. The total number of books in the home also did not affect macrostructure development. Overall, more significant correlations between narrative macrostructure and SES as well as HLE measures were expected, as found in a number of earlier studies (i.e. Alt et al. 2016, Bitetti \& Scheffner-Hammer 2016, Korat 2009, Mozzanica et al. 2016, Reese et al. 2009, Van Kleeck et al. 2011). The lack of statistically significant correlations might be due to a too small range of variance in the SES and HLE measures within the sample.

The aims of this study were to illustrate the development in narrative production skills like story structure and story complexity and comprehension skills in children aged $4 ; 6$ to $5 ; 11$ years, to work out differences regarding the narrative method (telling vs. retelling) and to analyse correlations between the narrative measures and aspects of the socio-economic status and home literacy environment. To summarize the results, there were significant age effects in story structure (telling and retelling), story complexity (telling) and story comprehension (telling and retelling), an overall effect of the narration method (retelling $>$ telling) and a weak correlation between the fathers educational background and the child's story comprehension after telling Baby Birds story. Limitations to this study are for example missing data regarding items of the parent questionnaire like the monthly family income and the positively skewed distribution of the parent's educational backgrounds as well as missing data according to story comprehension tasks. Furthermore, an alternate way of assessing the stories in telling and retelling mode would have allowed implications on developmental order. The current study thus opens up a number of avenues of research like a further analysis of age group effects in school-aged children, in bilingual children as well as children with specific language impairment. In addition, task effects and a deeper analysis of story structure elements may be interesting topics for further studies. ${ }^{1}$

1 Thanks to Dr. Josefin Lindgren, PD Dr. Natalia Gagarina and Prof. Dr. Katja Mackowiak for their feedback on earlier drafts of this paper. 
Development of narrative macrostructure in monolingual preschoolers in Germany and impact of socio-economic status and home literacy environment

\section{$7 \quad$ References}

Alt, M., Arizmendi, G.D. \& DiLallo, J.N. (2016). The Role of Socioeconomic Status in the Narrative Story Retells of School-Aged English Language Learners. Language, Speech and Hearing Services in Schools, 47, 313-323.

Armon-Lotem, S. de Jong, J. \& Meir, N. (2015). Assessing Multilingual Children Disentangling Bilingualism from Language Impairment. Bristol: UK: Multilingual Matters.

Arriaga, R.I., Fenson, L., Cronan, T. \& Pethick S.J. (1998). Scores on the MacArthur Communicative Development Inventory of children from low- and middle-income families. Applied Psycholinguistics, 19, 209-23.

Bartl, K., Vollmann, R., Strutzmann, E. \& Marschik, P.B. (2011). Erzählstrukturen bei 3- bis 6-jährigen Vorschulkindern. In Vollmann, R. \& Marschik, P.B. (Hrsg.). Grazer Linguistische Studien 75. 25-37. Graz: Universität Graz.

Becker, T. (2011). Kinder lernen erzählen. Zur Entwicklung der narrativen Fähigkeiten von Kindern unter Berücksichtigung der Erzählform. Hohengehren: Schneider.

Becker, T. \& Licandro, U. (2014). Prototypische Problembilder beim Erzählenlernen: Fallbeispiele mit Bezug auf Förderung und Therapie. Sprachförderung und Sprachtherapie, 2014, 140-146.

Berman, R.A. (2009). Language Development in Narrative Contexts. In Bavin, E. (Ed.). The Cambridge Handbook of Child Language. 355-375. Cambridge: Cambridge University Press.

Berman, R.A. \& Slobin, D.I. (Eds.). (1994). Relating events in narrative: A crosslinguistic developmental study. Mahwah, NJ: Lawrence Erlbaum Associates.

Bitetti, D. \& Scheffner Hammer, C. (2016). The Home Literacy Environment and the English Narrative Development of Spanish-English Bilingual Children. Journal of Speech, Language, and Hearing Research, 59, 1159-1171.

Bohnacker, U. (2016). Tell me a story in English or Swedish: Narrative production and comprehension in bilingual preschoolers and first graders. Applied Psycholinguistics, 37, 19-48.

Bowey, J.A. (1995). Socioeconomic status differences in preschool phonological sensitivity and first-grade reading achievement. Journal of Educational Psychology, 87, 476-87.

Bradley, R.H. \& Corwyn, R.F. (2002). Socioeconomic status and child development. Annual Review of Psychology, 53, 371-99.

Burchinal, M. R., Pace, A., Alper, R., Hirsh-Pasek, K., \& Golinkoff, R. M. (2016, July 1113). Early language outshines other predictors of academic and social trajectories in elementary school. Presented at the Administration for Children and Families (ACF) National Research Conference on Early Childhood. Washington, DC.

Burchinal, M.R., Peisner-Feinberg, E., Pianta, R. \& Howes, C. (2002). Development of academic skills from preschool through second grade: family and classroom predictors of developmental trajectories. Journal of School Psychology, 40, 415-36.

Burger, L.K. \& Miller, P.J. (1999). Early talk about the past revisited: a comparison of working-class and middle-class families. Journal of Child Language, 26, 1-30. 
Burris, S.E. \& Brown, D.D. (2014). When all children comprehend: increasing the external validity of narrative comprehension development research. Frontiers in Psychology, 5, 168.

Bus, A.G., van IJzendoorn, M.H. \& Pellegrini, A.D. (1995). Joint Book Reading Makes for Success in Learning to Read: A Meta-analysis on Intergenerational Transmission of Literacy. Review of Educational Research, 65, 1-21.

Carroll, C.J. (2013). The Effects of Parental Literacy Involvement and Child Reading Interest on the Development of Emergent Literacy Skills. UWM Digital Commons. Theses and Dissertations. Paper 230.

Cartmill, E.A., Armstrong, B.F., Gleitman, L.R., Goldin-Meadow, S., Medina, T.N. \& Trueswell, J.C. (2013). Quality of early parent input predicts child vocabulary 3 years later. Proceedings of the National Academy of Sciences of the United States of America, 110, 11278-83.

Corsaro, W.A., Molinari, L. \& Rosier, K.B. (2002). Zena and Carlotta: transition narratives and early education in the United States and Italy. Human Development, 45, 323-48.

Crain-Thoreson, C. \& Dale, P.S. (1992). Do Early Talkers Become Early Readers? Linguistic Precocity, Preschool Language, and Emergent Literacy. Developmental Psychology, 28, 421-429.

De Graaf, P.M. (1988). Parents' Financial and Cultural Resources, Grades, and Transition to Secondary School in the Federal Republic of Germany. European Sociological Review, 4, 209-221.

Dickinson, D.K. \& Tabors, P.O. (2001). Beginning Literacy with Language. Baltimore, MD: Paul H. Brookes.

Duncan, G.J., Brooks-Gunn, J. \& Klebanov, P.K. (1994). Economic deprivation and early childhood development. Child Development, 65, 296-318.

Duncan, G.J., Magnuson, K. \& Votruba-Drzal, E. (2015). Children and socioeconomic status. In R.M. Lerner, M.H. Bornstein \& T. Leventhal (Eds.). Handbook of Child Psychology and Developmental Science 4, 534-73. Hoboken: Wiley.

Ensminger, M.E. \& Fothergill, K. (2003). A decade of measuring SES: what it tells us and where to go from here. In M.H. Bornstein \& R.H. Bradley (Eds.). Socioeconomic Status, Parenting, and Child Development. 13-27. Mahwah: Erlbaum.

Entwisle, D.R. \& Alexander, K.L. (1999). Early schooling and social stratification. In R.C. Pianta \& M. Cox (Eds.). The Transition to Kindergarten: Research, Policy, Training, and Practice. 13-38. Baltimore: Paul H. Brookes.

Esping-Andersen, G. (2004). Untying the Gordian Knot of Social Inheritance. Research in Social Stratification and Mobility, 21, 115-138.

Fernald, A., Marchman, V. \& Weisleder, A. (2013). SES differences in language processing skill and vocabulary are evident at 18 months. Developmental Science, 16, 234-48.

Fletcher, K.L., Cross, J. R., Tanney, A. L., Schneider, M., \& Finch, W. H. (2008). Predicting language development in children at risk: The effects of quality and frequency of caregiver reading. Early Education and Development, 19, 89-111.

Gagarina, N. (2016). Narratives of Russian-German preschool and primary school bilinguals: Rasskaz and Erzaehlung. Applied Psycholinguistics, 37, 11-17.

Gagarina, N., Klop, D., Kunnari, S., Tantele, K., Välimaa, T., Balčiūnienė, I., Bohnacker, U. \& Walters, J. (2015). Assessment of narrative abilities in bilingual children. In S. 
Armon-Lotem, J. de Jong \& N. Meir (Eds.). Language Impairment Testing in Multilingual Settings. 241-274. Amsterdam: John Benjamins.

Gagarina, N., Klop, D., Kunnari, S., Tantele, K., Välimaa, T., Balčiūnienė, I., Bohnacker, U. \& Walters, J. (2012). MAIN - Multilingual Assessment Instrument for Narratives. ZAS Papers in Linguistics, 56.

Gardner-Neblett, N., Pungello, E.P. \& Iruka, I.U. (2012). Oral narrative skills: implications for the reading development of African American children. Child Development Perspectives, 6, 218-24.

Gillam, R.B. \& Pearson, N.A. (2004). Test of narrative language (TNL). Austin, TX: Pro Ed.

Ginsborg, J. (2006). The effects of socio-economic status on children's language acquisition and use. In J. Clegg \& J. Ginsborg (Eds.). Language and Social Disadvantage: Theory into Practice. 9-27. Hoboken: Wiley.

Goldin-Meadow, S., Levine, S.C., Hedges, L.V., Huttenlocher, J., Raudenbush, S.W. \& Small, S.L. (2014). New evidence about language and cognitive development based on a longitudinal study. American Psychologist, 69, 588-99.

Gutiérrez-Clellen, V.F. (2002). Narratives in two languages: Assessing performance of bilingual children. Linguistics and Education, 13, 175-197.

Hamilton, L.G., Hayiou-Thomasb, M.E., Hulmec, C. \& Snowling, M.J. (2016). The Home Literacy Environment as a Predictor of the Early Literacy Development of Children at Family-Risk of Dyslexia. Scientific Studies of Reading 20, 401-419.

Hart, B. \& Risley, T.R. (1995). Meaningful Differences in the Everyday Experience of Young American Children. Baltimore: Paul H. Brookes.

Hart, B. \& Risley, T.R. (1999). The Social World of Children: Learning to Talk. Baltimore: Paul H. Brookes.

Heilmann, J., Miller, J.F., Nockerts, A. \& Dunaway, C. (2010). Properties of the narrative scoring scheme using narrative retells in young school-age children. American Journal of Speech-Language Pathology, 19, 154-166.

Hindman, A., H., Connor, C. M., Jewkes, A. M., \& Morrison, F. J. (2008). Untangling the effects of shared book reading: Multiple factors and their associations with preschool literacy outcomes. Early Childhood Research Quarterly, 23, 330-350.

Hoff, E. (2013). Interpreting the early language trajectories of children from low-SES and language minority homes: implications for closing achievement gaps. Developmental Psychology, 49, 4-14.

Hoff, E. (2006). How social contexts support and shape language development. Developmental Review, 26, 55-88.

Hoff, E., Laursen, B. \& Bridges, K. (2002). Measurement and model building in studying the influence of socioeconomic status on child development. In M. Lewis \& L. Mayes (Eds.). A Developmental Environmental Measurement Handbook. 590-606. New York: Cambridge University Press.

International Labour Organization (2008). ISCO $08 . \quad$ URL: http://www.ilo.org/public/english/bureau/stat/isco/isco08/

Isbell, R., Sobol, J., Lindauer, L. \& Lowrance, A. (2004). The Effects of Storytelling and Story Reading on the Oral Language Complexity and Story Comprehension of Young Children. Early Childhood Education Journal, 32, 157-163. 
Justice, L. M., \& Pullen, P.C. (2003). Promising interventions for promoting emergent literacy skills: Three evidence-based approaches. Topics in Early Childhood Special Education, 23, 99-113.

Justice, L. M., Bowles, R. P., Kaderavek, J. N., Ukrainetz, T. A., Eisenberg, S. L., \& Gillam, R. B. (2006). The Index of Narrative Microstructure: A clinical tool for analyzing school-age children's narrative performances. American Journal of Speech-Language Pathology, 15, 177-191.

Kaikhosroshvili, K. (2016). Elicited vs. Recalled narrative skills in kindergartners from diverse linguistic backgrounds. Scholarly Undergraduate Research Journal at Clark, $2,18-24$.

Kapalková, S., Polisenská, K., Marková, L., \& Fenton, J. (2016). Narrative abilities in early successive bilingual Slovak-English children: A cross-language comparison. Applied Psycholinguistics, 37, 145-164.

Kemper, S. (1984). The development of narrative skills: Explanations and entertainments. In S. A. Kuczaj (Ed.). Discourse development. 99-124. New York: Academic Press.

Korat, O. (2009). The effect of maternal teaching talk on children's emergent literacy as a function of type of activity and maternal education level. Journal of Applied Developmental Psychology, 30, 34-42.

Kunnari, S., Välimaa, T. \& Laukkanen-Nevala, P. (2016). Macrostructure in the Narratives of Monolingual Finnish and Bilingual Finnish-Swedish Children. Applied Psycholinguistics, 37, 123-144.

Leseman, P.P.M., Scheele, A.F., Mayo, A.Y. \& Messer, M.H. (2007). Home Literacy as a Special Language Environment to Prepare Children for School. Zeitschrift für Erziehungswissenschaft, 10, 334-355.

Liles, B.Z., Duffy, R.J., Merritt, D.D. \& Purcell, S.L. (1995). Measurement of narrative discourse ability in children with language disorders. Journal of Speech and Hearing Research, 38, 415-425.

Lindgren, J. (2018). Developing narrative competence. Swedish, Swedish-German and Swedish-Turkish children aged 4-6. (Studia Linguistica Upsaliensia 19). Uppsala: Acta Universitatis Upsaliensis.

MacWhinney, B. (2000). The CHILDES project: Tools for analyzing talk. Mahwah, NJ: Lawrence Erlbaum Associates.

Magnuson, K.A., Sexton, H.R., Davis-Kean, P.E. \& Huston, A.C. (2009). Increases in maternal education and young children's language skills. Merrill-Palmer Quarterly, $55,319-50$.

Mandler, G. (1979). Organization and repetition: Organization principles with special reference to rote learning. In L. Nilsson (Ed.). Perspectives on memory research. 293327. Hillsdale: Erlbaum.

Maviş, I., Tunçer, M. \& Gagarina, N. (2016). Macrostructure Components in Narrations of Turkish-German Bilingual Children. Applied Psycholinguistics, 37, 69-89.

Mayer, M. (2003). Frog, where are you? New York: Dial books.

McCabe, A. \& Peterson, C. (1984). What makes a good story? Journal of Psycholinguistic Research, 13, 457-480.

McLoyd, V.C. (1998). Socioeconomic disadvantage and child development. American Psychologist, 53, 185-204. 
Mol, S.E., Bus, A.G., de Jong, M.T., \& Smeets, D.J.H. (2008). Added Value of Parent-Child Dialogic Readings: A Meta-analysis. Early Education and Development, 19, 7-26.

Mozzanica, F., Ambrogi, F., Salvadorini, R., Sai, E., Pozzoli, R., Barillari, M.R., Scarponi, L. \& Schindler, A. (2016). The Relationship between Socioeconomic Status and Narrative Abilities in a Group of Italian Normally Developing Children. Folia Phoniatrica et Logopaedica, 68, 134-140.

Muñoz, M.L., Gillam, R.B., Peña, E.D. \& Gulley-Faehnle, A. (2003). Measures of language development in fictional narratives of Latino children. Language, Speech \& Hearing Services in the Schools 34, 332-342.

Nelson, K. (2010). Developmental Narratives of the Experiencing Child. Child Development Perspectives, 4, 42-47.

Nicolopoulou, A., Brockmeyer, C., de Sá, A. \& Ilgaz, H. (2014). Narrative Performance, Peer Group Culture, and Narrative Development in a Preschool Classroom. In A. Cekaite, S. Blum-Kulka, V. Grover \& E. Teubal (Eds.). Children's Peer Talk: Learning from Each Other. 42-62. New York: Cambridge University Press.

Noble, K.G., Engelhardt, L.E., Brito, N.H., Mack, L.J. \& Nail, E.J. (2015). Socioeconomic disparities in neurocognitive development in the first two years of life. Developmental Psychobiology, 57, 535-51.

Norbury, C.F. \& Bishop, D.V.M. (2003). Narrative skills of children with communication impairments. International Journal of Language and Communication Disorders, 38, 287-313.

OECD (2014). Do parents' occupations have an impact on student performance? PISA in Focus 2014, 02. http://www.oecd.org/pisa/pisaproducts/pisainfocus/PISA-in-FocusN36-\%28eng\%29-FINAL.pdf

Oktay, S.A. (2010). A Sociolinguistic Perspective in Narrative Analysis: Educational Backgrounds of Families as Influential Factors in the Development of Personal Experience Child Narratives. Dilbilim Araştırmaları, 2010, 73-92.

O`Neill, D.K., Pearce, M.J. \& Pick, J.L. (2004). Preschool children’s narratives and performance on the Peabody Individualized Achievement Test - Revised: Evidence of a relation between early narrative and later mathematical ability. First Language, 24, 149-183.

Otwinowska, A., Mieszkowska, K., Białecka-Pikul, M., Opacki, M. \& Haman, E. (2018). Retelling a model story improves the narratives of Polish-English bilingual children. International Journal of Bilingual Education and Bilingualism, https://doi.org/10.1080/13670050.2018.1434124

Pace, A., Luo, R., Hirsh-Pasek, K. \& Michnick Golinkoff, R. (2017). Identifying Pathways Between Socioeconomic Status and Language Development. Annual review of applied linguistics, 2017, 285-308.

Pavlenko, A. (2008). Narrative analysis. In L. Wei \& M. G. Moyer (Eds.). The Blackwell guide to research methods in bilingualism and multilingualism (311-325). Malden, MA: Blackwell.

Peterson, C. (1994). Narrative skills and social class. Canadian Journal of Education, 19, 251-69.

Peterson, C. \& McCabe, A. (1991). Developmental psycholinguistics: Three ways of looking at a child's narrative. New York, NY: Plenum Press. 
Phillips, B.M., \& Lonigan, C.J. (2009). Variations in the home literacy environment of preschool children: A cluster analytic approach. Scientific Studies of Reading, 13, $146-174$.

Puglisi, M.L., Hulme, C., Hamilton, L.G. \& Snowling, M.J. (2017). The Home Literacy Environment Is a Correlate, but Perhaps Not a Cause, of Variations in Children's Language and Literacy Development. Scientific Studies of Reading, 21, 498-514.

Pungello, E.P., Iruka, I.U., Dotterer, A.M., Mills-Koonce, R. \& Reznick, J.S. (2009). The effects of socioeconomic status, race, and parenting on language development in early childhood. Developmental Psychology, 45, 544-557.

Raven, J.C, Bulheller, J. \& Häcker, J.H. (2001). Coloured Progressive Matrices (CPM). Frankfurt: Pearson.

Reese, E., Suggate, S., Long, J. \& Schaughency, E. (2009). Children's Oral Narrative and Reading Skills in the First Three Years of Reading Instruction. Reading and Writing: An Interdisciplinary Journal, DOI 10.1007/s11145-009-9175-9

Ringmann, S. (2014). Therapie der Makrostruktur von Erzählungen. Sprachförderung und Sprachtherapie, 2014, 147-155.

Ringmann, S. (2013). Therapie der Erzählfähigkeit. In: Ringmann, S. \& Siegmüller, J. (Eds.), Handbuch Spracherwerb und Sprachentwicklungsstörungen. Schuleingangsphase. Munich: Elsevier.

Roch, M., Florit, E. \& Levorato, C. (2016). Narrative competence of Italian-English bilingual children between 5 and 7 years. Applied Psycholinguistics, 37, 49-67.

Rodriguez, E.T. \& Tamis-LeMonda, C.S. (2011). Trajectories of the home learning environment across the first 5 years: associations with children's vocabulary and literacy skills at prekindergarten. Child Development, 82, 1058-75.

Rowe, M.L. (2012). A longitudinal investigation of the role of quantity and quality of childdirected speech in vocabulary development. Child Development, 83, 1762-74.

Scarborough, H.S. \& Dobrich, W. (1994). On the Efficacy of Reading to Preschoolers. Developmental Review, 14, 245-302.

Schöler, H. \& Brunner, M. (2008). Heidelberger auditives Screening in der Einschulungsuntersuchung (HASE). Westra.

Schulz, P. \& Tracy, R. (2011). Linguistische Sprachstandserhebung - Deutsch als Zweitsprache (Lise DaZ). Göttingen: Hogrefe.

Schütz, G., Ursprung, H.W. \& Wößmann, L. (2008). Education Policy and Equality of Opportunity. Kyklos, 61, 279-308.

Schütz, G. \& Wößmann, L. (2005). Wie lässt sich die Ungleichheit der Bildungschancen verringern? ifo Schnelldienst, 58, 15-25.

Sénéchal, M., Pagan, S., Lever, R. \& Ouellette, G.P. (2008). Relations among the Frequency of Shared Reading and 4-Year-Old Children's Vocabulary, Morphological and Syntax Comprehension, and Narrative Skills. Early Education and Development, 19, 27-44.

Shiro, M. (2003). Genre and evaluation in narrative development. Journal of Child Language, 30, 165-195.

Spencer, T.D., Kajian, M., Petersen, D.B. \& Bilyk, N. (2013). Effects of an individualized narrative intervention on children's storytelling and comprehension skills. Journal of Early Intervention, 35, 243-269. 
Stein, N.L. (1988). The Development of Children's Storytelling Skill. In M.B. Franklin \& S.S. Barten (Eds.). Child Language: A Reader. 282-297. New York: Oxford University Press.

Stein, N.L. \& Glenn, C.G. (1979). An analysis of story comprehension in elementary school children. In R.O. Freedle (Eds.), Discourse processing: Multidisciplinary perspectives. Norwood, NJ: Ablex.

Taylor, B.A., Dearing, E. \& McCartney, K. (2004). Incomes and outcomes in early childhood. Journal of Human Resources, 39, 980-1007.

Trabasso, T. \& Nickels, M. (1992). The development of goal plans of action in the narration of a picture story. Discourse Processes, 15, 249-275.

Trabasso, T., \& Rodkin, P. C. (1994). Knowledge of goal/plans: A conceptual basis for narrating "Frog where are you?" In R.A. Berman \& D.I. Slobin (Eds.). Relating events in narrative: A cross-linguistic developmental study. 85-106. New York: Psychology Press.

Tsimpli, I. M., Peristeri, E., \& Andreou, M. (2016). Narrative production in monolingual and bilingual children with specific language impairment. Applied Psycholinguistics, 37, 195-216.

Ukrainetz, T.A., Justice, L.M., Kaderavek, J.N., Eisenberg, S.L., Gillam, R.B. \& Harm, H.M. (2005). The Development of Expressive Elaboration in Fictional Narratives. Journal of Speech, Language and Hearing Research, 48, 1363-1377.

Van Kleeck, A., Lange, A. \& Schwarz, A.L. (2011). The effect of race and maternal education level on children's retells of the Renfrew Bus Story-North American Edition. Journal of Speech, Language, and Hearing Research, 54, 1546-1561.

Van Kleeck, A., Gillam, R.B., Hamilton, L., \& McGrath, C. (1997). The relationship between middle-class parents' book-sharing discussion and their preschoolers. Journal of Speech, Language, and Hearing Research, 40, 1261-1272.

Vygotsky, L. (1962). Thought and Word. In L. Vygotsky, E. Hanfmann \& G. Vakar (Eds.). Thought and Language. 119-153. Cambridge, MA: MIT Press.

Walker, D., Greenwood, C., Hart, B. \& Carta, J. (1994). Prediction of school outcomes based on early language production and socioeconomic factors. Child Development, 65, 606-621.

Westby, C.E. (2005). Assessing and facilitating text comprehension problems. In H. Catts \& A. Kamhi (Eds.). Language and reading disabilities. 157-232. Boston, MA: Allyn \& Bacon.

Whitehurst, G.J., Arnold, D.S., Epstein, J.N., Angell, A.L., Smith, M. \& Fischel, J.E. (1994). A Picture Book Reading Intervention in Day Care and Home for Children from Low Income Families'. Developmental Psychology, 30, 679-89.

Whitehurst, G.J. \& Lonigan, C.J. (1998). Child Development and Emergent Literacy. Child Development, 69, 848-72. 